\title{
New developments in the representation of Saharan dust sources in the aerosol-climate model ECHAM6-HAM2
}

\author{
Bernd Heinold $^{1}$, Ina Tegen ${ }^{1}$, Kerstin Schepanski ${ }^{1}$, and Jamie R. Banks ${ }^{1,2}$ \\ ${ }^{1}$ Leibniz Institute for Tropospheric Research (TROPOS), Leipzig, Germany \\ ${ }^{2}$ Space and Atmospheric Physics Group, The Blackett Laboratory, Imperial College London, London, UK \\ Correspondence to: Bernd Heinold (heinold@tropos.de)
}

Received: 6 July 2015 - Published in Geosci. Model Dev. Discuss.: 11 September 2015

Revised: 29 January 2016 - Accepted: 1 February 2016 - Published: 25 February 2016

\begin{abstract}
In the aerosol-climate model ECHAM6-HAM2, dust source activation (DSA) observations from Meteosat Second Generation (MSG) satellite are proposed to replace the original source area parameterization over the Sahara Desert. The new setup is tested in nudged simulations for the period 2007 to 2008 . The evaluation is based on comparisons to dust emission events inferred from MSG dust index imagery, Aerosol Robotic Network (AERONET) sun photometer observations, and satellite retrievals of aerosol optical thickness (AOT).
\end{abstract}

The model results agree well with AERONET measurements especially in terms of seasonal variability, and a good spatial correlation was found between model results and MSG-SEVIRI (Spinning-Enhanced Visible and InfraRed Imager) dust AOT as well as Multi-angle Imaging SpectroRadiometer (MISR) AOT. ECHAM6-HAM2 computes a more realistic geographical distribution and up to $20 \%$ higher annual Saharan dust emissions, using the MSG-based source map. The representation of dust AOT is partly improved in the southern Sahara and Sahel. In addition, the spatial variability is increased towards a better agreement with observations depending on the season. Thus, using the MSG DSA map can help to circumvent the issue of uncertain soil input parameters.

An important issue remains the need to improve the model representation of moist convection and stable nighttime conditions. Compared to sub-daily DSA information from MSGSEVIRI and results from a regional model, ECHAM6HAM2 notably underestimates the important fraction of morning dust events by the breakdown of the nocturnal lowlevel jet, while a major contribution is from afternoon-toevening emissions.

\section{Introduction}

Soil dust, which makes up the largest part of the global aerosol burden, represents an important factor in the Earth system. Airborne dust particles can affect the climate directly by aerosol-radiation interactions or indirectly by modifying cloud properties, atmospheric dynamics, and the biogeochemical cycle (Carslaw et al., 2010; Shao et al., 2011). In addition, mineral dust can cause serious air-quality issues with potential effects on human health, transportation, and solar energy production (Griffin, 2007; Breitkreuz et al., 2007). Despite its large potential impact, considerable uncertainties remain in the estimates of the budget and climate effects of mineral dust (e.g., Boucher et al., 2013; Mulcahy et al., 2014). Since the Sahara is the most important dust source worldwide, contributing at least $50 \%$ to the global dust load (Huneeus et al., 2011; Ginoux et al., 2012), it is of particular importance to consider the dust from this region.

The impact of mineral dust upon climate and the feedback of changing climate conditions on dust emission and transport have been investigated largely by general circulation modeling. A test of 14 state-of-the-art global models within the global aerosol model intercomparison (AeroCom) exercise (Schulz et al., 2009) shows that the seasonal cycle and long-range transport of mineral dust is generally well represented in those models. However, large discrepancies exist in the modeled estimates of dust emission, which differ by a factor of about 5 globally and for North Africa (Textor et al. 2006; Huneeus et al., 2011). The large spread in the model results indicates that dust emission processes are not fully adequately resolved in current global models, which is attributed to uncertainties in the prescribed soil properties (texture, soil moisture) and the representation of meteorolog- 
ical drivers of dust emission (Knippertz and Todd, 2012, and references therein). To assess which of the sources of uncertainty has the largest effect on the model results is difficult because of the complexity of involved processes and feedbacks within the coupled models. Due to the high sensitivity of dust emission to the upper range of the wind speed distribution, however, the representation of, in particular, subgridscale meteorological processes can be more important than differences in the dust emission scheme or soil characteristics (Luo et al., 2003; Menut, 2008). Different meteorological processes have been identified as potential generators for dust emissions. While synoptic-scale meteorological patterns are usually well reproduced, simulations of dust emissions due to moist convection (Knippertz et al., 2009; Reinfried et al., 2009; Heinold et al., 2013) or micro-scale dry convective events (e.g., dust devils, Koch and Renno, 2005; JemmettSmith et al., 2015) are challenging.

A member of the AeroCom study is the global aerosolclimate model ECHAM5-HAM. The dust emissions from this model (Sahara: $400 \mathrm{Tg} \mathrm{yr}^{-1}$; global: $585 \mathrm{Tg} \mathrm{yr}^{-1}$ ) range at the lower end of current model estimates (Huneeus et al., 2011), which, however, may be largely related to a small maximum dust particle size compared to other AeroCom members. The current version ECHAM6-HAM2 provides global emission fluxes of 948 and $552 \mathrm{Tg} \mathrm{yr}^{-1}$ from North African dust sources (2007-2008 mean from this study). Whereas the considerable increase in global dust emissions is mainly due to improvements for East Asian dust sources (Cheng et al., 2008; Zhang et al., 2012), the dust parameterization has remained unchanged for the Sahara, and the higher values result from developments of the driving model ECHAM6. The global model uses the dust emission scheme by Tegen et al. (2002), which is also implemented and has been further refined in the regional-scale $\mathrm{Sa}$ haran dust model COSMO-MUSCAT (Heinold et al., 2007, 2011). In this work we present simulations of Saharan dust for the years 2007 and 2008 using the current version of ECHAM6-HAM2, which is updated with the recent developments from the regional model. For the evaluation of modeled dust emission events and the distribution of Saharan dust, dust source activation (DSA) observations from the Meteosat Second Generation (MSG) satellite, standard sun photometer measurements provided through Aerosol Robotic Network (AERONET), and satellite retrievals of dust aerosol optical thicknesses are used.

\section{Methods}

\subsection{Model description}

In this study we use the current version of the aerosolclimate modeling system ECHAM-HAMMOZ (version echam6.1-ham2.2-moz0.9) that was first described by Stier et al. (2005). It consists of the global circulation model
ECHAM6 (Stevens et al., 2013) and the aerosol-chemistry and microphysics package HAM2 (Zhang et al., 2012).

ECHAM6-HAM2 simulates the global formation, transport, and removal of aerosol particles in the atmosphere, their processing and interactions. Aerosol populations, which can be internally or externally mixed, are described by a superposition of seven log-normal modes. The emissions of desert dust and marine aerosol are computed online, based on the ECHAM6 meteorology. Emissions of anthropogenic species are prescribed. The aerosol removal from the atmosphere is due to sedimentation, dry and wet deposition, and is parameterized depending on particle size, composition, and mixing state.

The modeled aerosol distribution can affect the climate simulations through interactions with radiation and clouds. A look-up table with Mie pre-calculated parameters is used to dynamically determine the particle optical properties considering their actual size, composition, and water content (Stier et al., 2005; Zhang et al., 2012). The description of cloud microphysics in ECHAM6-HAM2 is based on the two-moment scheme of Lohmann et al. (2007), which allows for accounting for the impact of modeled aerosol populations on the number concentration of cloud condensation and ice nuclei. For further details of the model system we refer to Stier et al. (2005) and Zhang et al. (2012).

In the standard version of ECHAM6-HAM2.1, dust emissions are calculated interactively using the scheme of Tegen et al. (2002), including updates for East Asian dust source regions from Cheng et al. (2008). The dust emission fluxes are computed as a function of the third power of the wind friction velocity, based on the ECHAM6-predicted wind speed and soil moisture. The dust uplift occurs above a certain threshold of friction velocity $\left(U_{\mathrm{t}}^{*}\right)$, which depends on the diameter of erodible soil particles $\left(D_{\mathrm{p}}\right)$, the local roughness length of the overall surface $\left(Z_{0}\right)$, and the local roughness length of the erodible (smooth) surface $\left(z_{0 \mathrm{~s}}\right)$. The computation of the sizedependent threshold friction velocity $\left(U_{t}^{*}\right)$ follows Marticorena and Bergametti (1995), including a drag partition parameterization, which addresses the impact of non-erodible roughness elements on $U_{\mathrm{t}}^{*}$ by sheltering loose, erodible particles from wind erosion:

$$
U_{\mathrm{t}}^{*}\left(D_{\mathrm{p}}, Z_{0}, z_{0 s}\right)=\frac{U_{\mathrm{t}}^{*}\left(D_{\mathrm{p}}\right)}{f_{\mathrm{eff}}\left(Z_{0}, z_{0 \mathrm{~s}}\right)},
$$

with

$$
f_{\text {eff }}\left(Z_{0}, z_{0 \mathrm{~s}}\right)=1-\left[\ln \left(\frac{Z_{0}}{z_{0 \mathrm{~s}}}\right) / \ln \left(0.35\left(\frac{10}{z_{0 \mathrm{~s}}}\right)^{0.8}\right)\right] \text {. }
$$

Here, $f_{\text {eff }}$ is the efficient friction velocity ratio defined as the ratio of local to total friction. In ECHAM6-HAM2.1, the roughness length $Z_{0}$ is set default to the constant value of smooth roughness length $z_{0 \mathrm{~s}}$ of $0.001 \mathrm{~cm}$. Alternatively, the global satellite-based data set of aerodynamic roughness length from Prigent et al. (2005) can be used in the model 

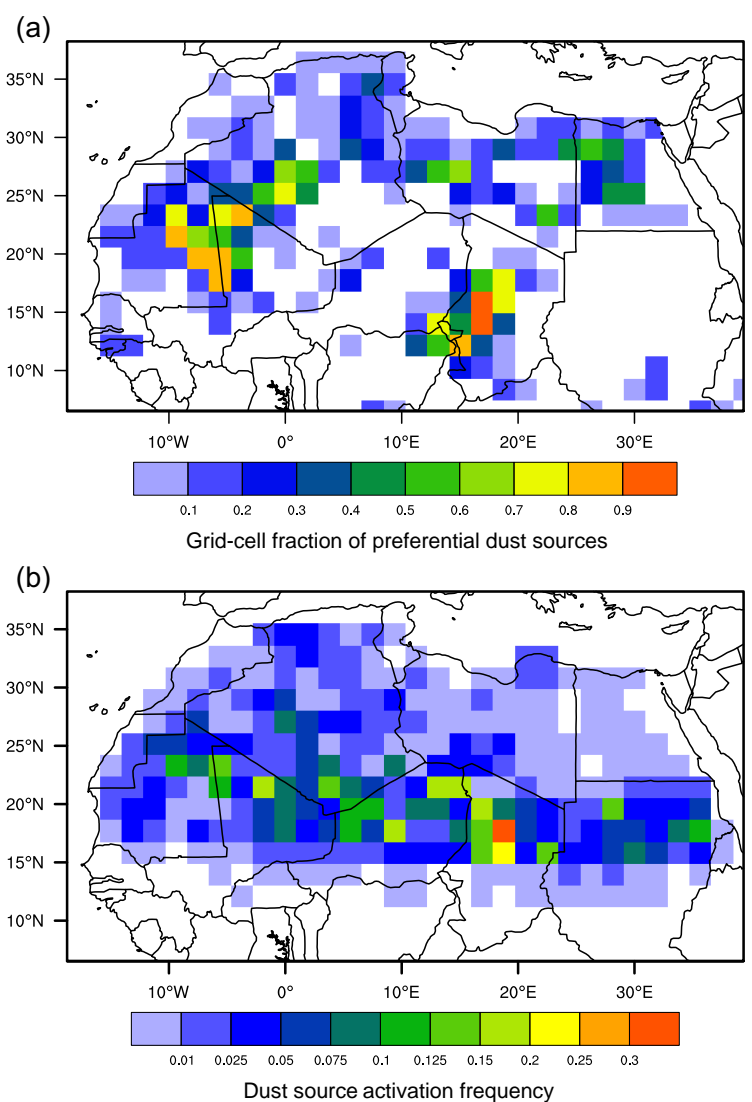

Figure 1. Preferential dust sources in the Sahara on a $1.875^{\circ} \times 1.875^{\circ}$ (T63) grid. (a) Grid-cell fraction covered by preferential dust sources calculated from the extent of potential lake areas (Tegen et al., 2002) and (b) dust source activation frequencies derived from the 15 min MSG-SEVIRI IR dust index for March 2006 to February 2010 (Schepanski et al., 2007, 2012).

(Cheng et al., 2008). The latter, however, caused overestimation of the dust optical depth over North Africa in previous tests (see Zhang et al., 2012 for details). Still, there is further potential for dust model improvements in a more sophisticated representation of surface roughness.

It is assumed that dust is preferentially emitted in enclosed topographic depressions, such as paleo- and temporal lake beds (see Fig. 1a for location), characterized by low surface roughness and large deposits of loose, fine soil particles (Prospero et al., 2002). Minor dust emissions can also occur in other sparsely or non-vegetated areas. The dust emission flux is computed for 192 internal size classes within the diameter range of $0.2-1300 \mu \mathrm{m}$, which are finally divided up into three log-normally distributed size modes. Freshly emitted dust particles are assigned to the insoluble accumulation and coarse modes having a mass median radius (standard deviation) of $0.37(1.59 \mu \mathrm{m})$ and $1.75(2.0 \mu \mathrm{m})$, respectively. Due to the short residence time and a minor impact on the radiation budget super-coarse dust particles are neglected (Stier et al., 2005; Cheng et al., 2008).

\subsection{New satellite-based Saharan dust source approach}

In general, the accuracy of dust emission computations depends on a realistic model representation of the dustgenerating winds. In addition, limitations are largely related to the uncertainties of available erodibility data, i.e., surface roughness and soil texture. Here, satellite-based information on the frequency of Saharan dust emission events as shown in Fig. $1 \mathrm{~b}$ can provide an alternative for the prescription of potential dust sources over North Africa. The information on the frequency of dust source activation (DSA) are based on the MSG SEVIRI (Spinning-Enhanced Visible and InfraRed Imager) infrared (IR) dust index and are available on a regular $1^{\circ} \times 1^{\circ}$ grid for the period March 2006 to February 2010 (Schepanski et al., 2007, 2012). This information was derived by utilizing the $15 \mathrm{~min}$ dust index fields where the high temporal resolution allowed identifying the dust plume origin by analyzing the dust plume movements.

Using the MSG-based data set in a model, dust emissions are only computed for grid cells, where the DSA frequency exceeds $1 \%$ over the base period March 2006 to February 2010 . The surface roughness $Z_{0}$ in those areas is set to the constant low value of the smooth roughness length $z_{0 \mathrm{~s}}=0.001 \mathrm{~cm}$, as in the original model, which results in a low threshold for dust mobilization typical for a fully erodible soil bed (see Eqs. 1 and 2). The threshold value was determined by sensitivity runs with the regional dust model system COSMO-MUSCAT (Heinold et al., 2007, 2011), which is also equipped with the Tegen et al. (2002) scheme updated with the MSG source map. The value of $1 \%$ corresponds to 4 active days per year and, was first suggested by Schepanski et al. (2007). Since then the MSG-based DSA frequency map has been successfully used in the regional model for case studies (Schepanski et al., 2009; Heinold et al., 2011) and multi-year Saharan dust simulations (Tegen et al., 2013). Of course, as for all satellite remote sensing, dust source detection from space is limited by the impact of clouds and high atmospheric moisture (Brindley et al., 2012). This effect, however, may average out to some extend over the 5year period and is also addressed by the low DSA frequency threshold in the model.

For testing the MSG source map, we use the nudged version of ECHAM6-HAM2.1. The simulations were carried out for the period 2007 to 2008 , using (1) the standard setup, with the original preferential source description from Tegen et al. (2002), (referred to as ORIG hereafter) and (2) masking emissions with the satellite-based Saharan DSA frequency map (referred to as MSG). As in the standard setup, a correction factor of 0.86 (Cheng et al., 2008) is applied to the threshold friction velocity for dust emission calculations in both simulations. This non-physical scaling is common in global models to compensate for the effects of resolution on dust emission processes (e.g., lower surface winds) and therefore to ensure reasonable global total dust production (e.g., Ridley et al., 2013). The model was run at T63L31 
$\left(1.875^{\circ}\right.$ grid spacing; 31 vertical model layers) resolution and was nudged to ERA-Interim meteorological re-analysis.

\subsection{Observational data for model evaluation}

Sun photometer measurements provided by the AERONET (Holben et al., 1998) are used for a quantitative model evaluation at specific locations for the years 2007 and 2008. The model results are compared to monthly averages of the observed coarse-mode aerosol optical thickness (AOT) at $500 \mathrm{~nm}$ wavelength, which is typically dominated by mineral dust and sea salt particles (O'Neill et al., 2003). The averages of modeled dust AOT only comprise the daytime period between 09:00 and 15:00 UTC since the measurements are limited to sunlight hours. There are only a limited number of continuous AERONET observations on the fringes and only one station in the center of the Sahara. The comparison is presented for the stations Blida, Algeria $\left(36.5^{\circ} \mathrm{N}, 2.9^{\circ} \mathrm{E}\right)$, and Saada, Morocco $\left(31.6^{\circ} \mathrm{N}, 8.2^{\circ} \mathrm{W}\right)$, situated in the northern part of North Africa, and Tamanrasset, Algeria $\left(22.8^{\circ} \mathrm{N}\right.$, $5.5^{\circ} \mathrm{E}$ ), in the central Sahara. In the main direction of Saharan dust transport across the Atlantic Ocean, the coastal site Dakar, Senegal $\left(14.4^{\circ} \mathrm{N}, 17.0^{\circ} \mathrm{W}\right)$, is chosen for the evaluation, and the station Agoufou, Mali $\left(15.3^{\circ} \mathrm{N}, 1.5^{\circ} \mathrm{W}\right)$, south of the Sahara in the Sahel (see Fig. 3a for the geographical location of the AERONET stations). For the period of interest, cloud-screened level 1.5 data are used for the majority of stations, as only at Blida the coarse-mode retrieval is provided at quality level 2.0 (cloud-screened and quality-assured).

In addition, new satellite retrievals of mineral dust over North Africa for 2008 are used. The model results are compared to the dust optical thickness at $550 \mathrm{~nm}$ that is derived from SEVIRI observations aboard the MSG satellite (Brindley and Russell, 2009; Banks and Brindley, 2013). The dust detections are based on raw data at $15 \mathrm{~min}$ temporal and about $3 \mathrm{~km}$ spatial resolution at nadir and are available hourly from 06:00 to 16:00 UTC each day on a $0.25^{\circ}$ grid.

Furthermore, the $555 \mathrm{~nm}$ aerosol optical thickness retrieved from measurements of the Multi-angle Imaging SpectroRadiometer (MISR) on NASA's TERRA satellite (Kahn et al., 2007, 2009) is used for model evaluation. The MISR data are provided at a spatial resolution of $17.6 \mathrm{~km}$ over land and ocean, but only at a daily temporal resolution as result of the orbit pattern of MISR, with daytime equator crossings at around 10:30 LT.

In the model evaluation, only those time periods are considered when satellite observations are available in order to account for the difference in sampling between satellite retrievals and model. On the satellite sampling side, the high temporal resolution of SEVIRI is worth being mentioned again, which means that it can very flexibly be used to match with both MISR and the model, at least during daylight hours.

The comparison to the two data sets allows for taking into account some measure of the uncertainty of satellite dust

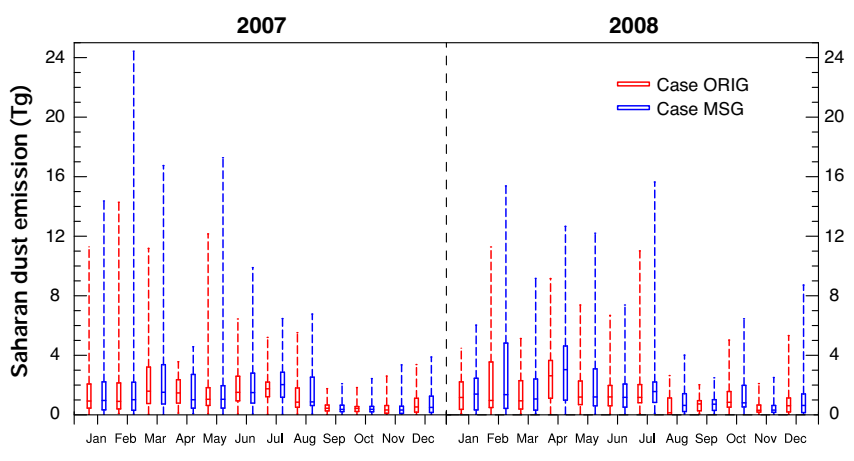

Figure 2. Monthly statistics of daily Saharan dust emissions for 2007 and 2008, computed by the ECHAM-HAM model with the MSG-based source mask (MSG, blue) and the original setup (ORIG, red). The lines of the boxes show the 25th, 50th (median) and 75th percentiles. Dashed lines indicate the range of values between minimum and maximum.

products. Space-borne remote sensing always suffers from the fact that dust information is obscured by clouds. Further potential issues for infrared retrievals like the SEVIRI dust AOT are high-columnar contents of atmospheric water vapor and the skin temperature, particularly over relatively cold surfaces at high altitude or over vegetated areas, where the thermal contrast between the surface and dust layer is reduced (Banks et al., 2013; Brindley et al., 2012; Kahn et al., 2010).

The DSA frequency information from MSG-SEVIRI is used in two ways: (1) using the spatial distribution of observed DSA frequencies to provide a mask for dust emissions as described in Sect. 2.2 to allow regions to be active dust sources as observed by the MSG dust index, but allowing the dust emission fluxes themselves to be simulated using the modeled surface friction velocities; and (2) using the temporal information of dust emission events from the MSG data to evaluate the temporal changes in DSA frequencies that are simulated by the model.

\section{Results}

\subsection{Saharan dust emissions}

The standard ECHAM6-HAM2 model computes an annual total of Saharan dust emissions of about 555 and $549 \mathrm{Tg} \mathrm{yr}^{-1}$ for the years 2007 and 2008. The modeled estimate, however, is increased by 15 to $22 \%$, respectively, when the MSGbased source description is used. Monthly statistics of the daily dust emissions over North Africa for the modeled period are presented in Fig. 2. It is known that the Saharan dust production is at a maximum from February to May and in the summer months June to September, while a minimum is found from October to January (e.g., Ben Ami et al., 2011). The model results are well in agreement with this seasonal cycle. In the ECHAM6-HAM2 standard run, the me- 

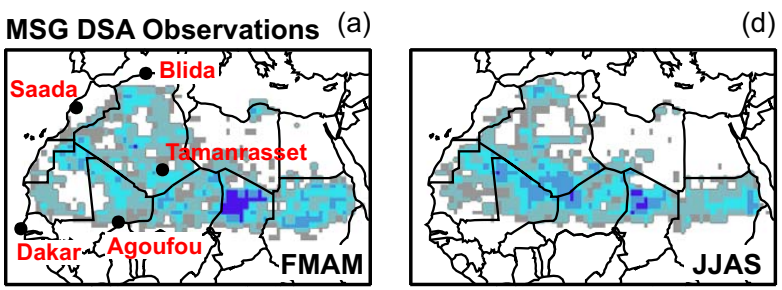

(d)
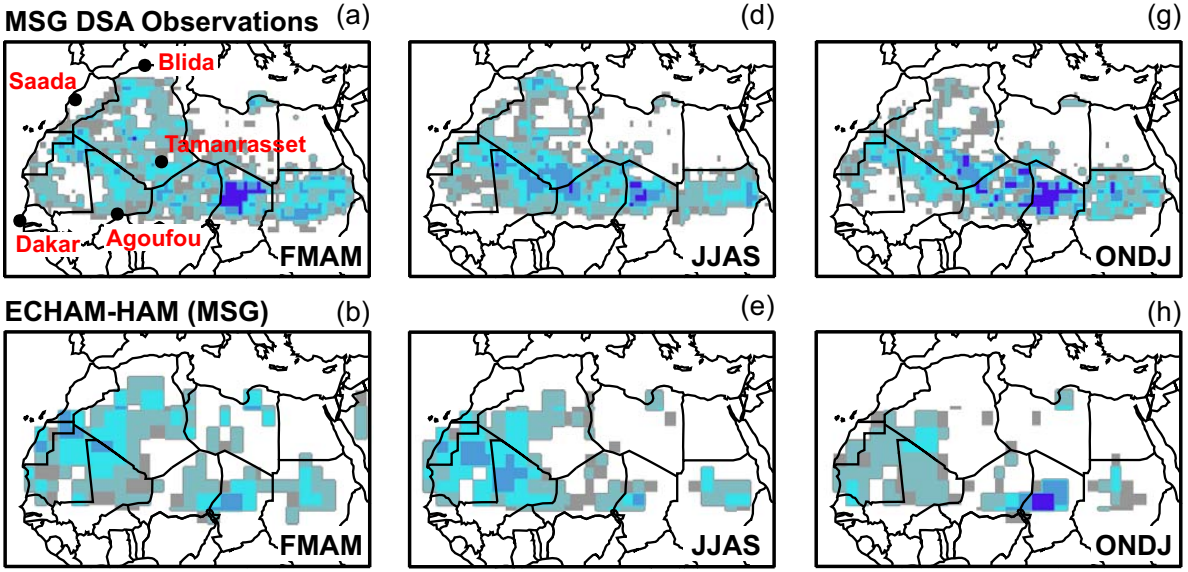

(e)
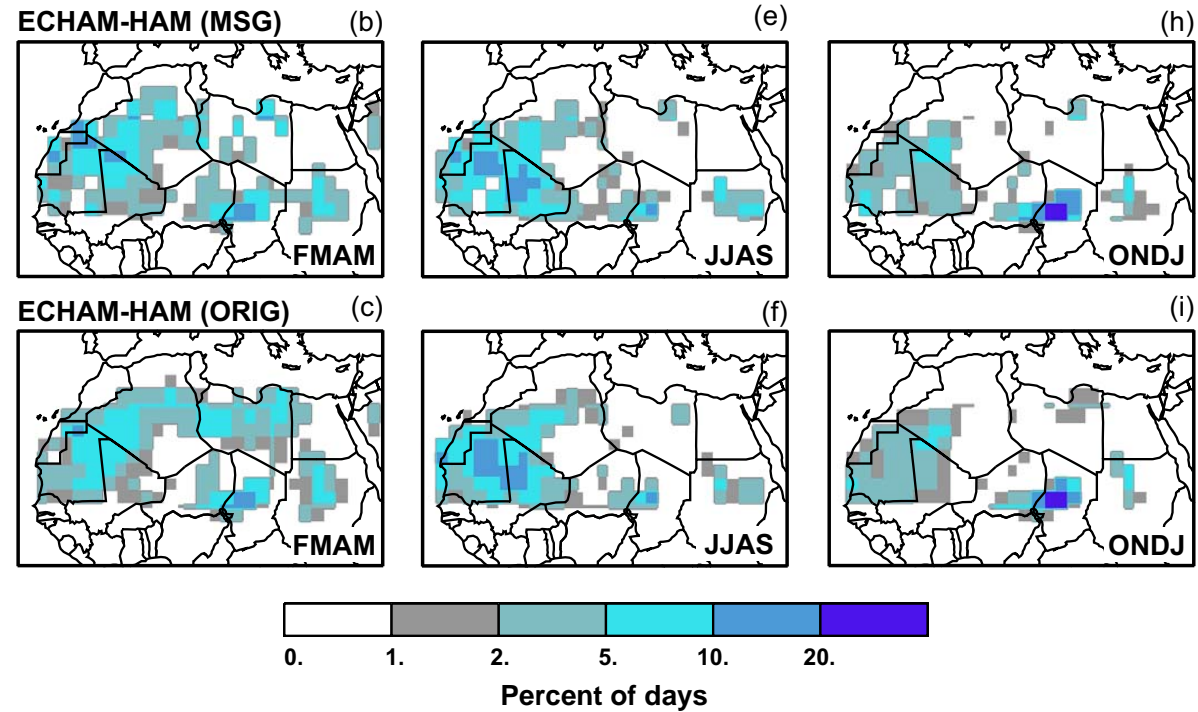

Figure 3. Saharan dust source activations in percent of days as (a, $\mathbf{d}, \mathbf{g})$ derived from MSG-SEVIRI dust index imagery and computed by ECHAM-HAM using $(\mathbf{b}, \mathbf{e}, \mathbf{h})$ the MSG-based source mask and $(\mathbf{c}, \mathbf{f}, \mathbf{i})$ the original map of preferential dust sources. Shown are average values for the years 2007 and 2008, averaged for the months (a-c) February to May, (d-f) June to September, and (g-i) October to January. Black dots in (a) indicate the location of AERONET stations used for model evaluation.

dian daily dust emission ranges between $0.5 \mathrm{Tg}$ in the fall and $2.5 \mathrm{Tg}$ during the active seasons. The increase in dust productivity is associated with a higher day-to-day variability with maximum daily dust emissions reaching up to $14 \mathrm{Tg}$. This is particularly the case for the period January to March, which is more characterized by episodic dust events (Knippertz and Todd, 2012).

Using the MSG-based dust source mask, the maximum daily emissions increase significantly compared to the original setup, with values up to $24 \mathrm{Tg}$. The differences in the median, however, are less important, except for the months July and August. Larger differences in the median between the two model runs also exist in February and April 2008. The higher maximum dust emissions in summer are mainly related to areas in the southern Sahara and Sahel, where more dust sources are activated in the model run with the MSG source mask.

The distribution of Saharan dust emission events simulated by the ECHAM6-HAM2 model is compared to MSG DSA frequencies for the years 2007 and 2008 in Fig. 3. For the direct comparison with the ECHAM6-HAM2 results, the MSG data were remapped to model resolution T63. The frequency of modeled dust emissions was derived applying a lower emission flux limit of $1.5 \times 10^{-4} \mathrm{~kg} \mathrm{~m}^{-2}$ per grid cell in a $3 \mathrm{~h}$ time interval. The threshold excludes minor dust events, which would remain undetected, and was chosen to have approximately equal dust emission counts for the $\mathrm{Sa}-$ hara within the 2-year period in both model results and observations. The 2-year total of modeled dust emission counts for the Sahara is 31.312 (31.300) for the model run with the MSG source mask (original setup) and 29.733 for the MSG data. The maps in Fig. 3 show averages for months, in which similar meteorological processes control the dust emissions.

From February to May (FMAM), intense Saharan cyclones along the North African coast (Hannachi et al., 2011; Fiedler et al., 2014) cause major dust emissions in the northern Sahara. In the central and southern Sahara and the Sahel, dust events are often related to enhanced northeasterly harmattan winds resulting from intensifications of the subtropical high (Kalu, 1979; Knippertz et al., 2011). In addition, the breakdown of the nocturnal low-level jet (LLJ) is a key driver of Saharan dust emissions throughout the year (e.g., Knippertz, 2008; Schepanski et al., 2009; Fiedler et al., 2013). While synoptic-scale features leading to dust emissions are expected to be well reproduced in a global-scale model, it is challenging for such a model to reproduce dust emissions by mesoscale features connected to boundary layer or convective processes. In general, the model well reproduces the ex- 
pected patterns of Saharan dust emissions in both model runs. However, the placement and number of dust events overall looks more realistic when the ECHAM6-HAM2 model is run using the MSG-based source mask (Fig. 3a-c). There is a more realistic distribution over West Africa, in particular Mauritania. In comparison to the original setup, this run also simulates more events south of the Anti-Atlas range and less extended source activations mainly over Libya.

In the summer months June to September (JJAS) (Fig. 3df), African easterly waves (AEWs) and the Saharan heat low (SHL) mainly control the dust uplift over West Africa (Knippertz and Todd, 2012). Dust-emitting winds result either directly from intense AEW disturbances and accelerations at the monsoon front or from the increased formation of LLJs and deep moist convection. The cold-pool outflow from mesoscale convective systems (often referred to as haboobs) is the major cause for dust emissions in the southern Sahara and Sahel (Marsham et al., 2013; Heinold et al., 2013). It is evident from the MSG observations that in both runs dust emission events are generally missing in the foothills of the mountains like the Tell Atlas and Saharan Atlas range as well as the Hoggar and Ennedi mountains. More dust sources are activated in southern Sahara and Sahel in the ECHAM6HAM2 run with the MSG source mask. Other minor improvements include the more correctly placed dust source near the coast of the Gulf of Sidra in northeastern Libya.

The Bodélé depression is the dominant dust source in the Sahara in the winter months October to January (ONDJ) (Fig. 3g-i). Both model runs show a good agreement with observations in this region. Using the MSG source mask, the model results show more but less extended, and therefore more realistic, activation events near the Libyan coast. The widespread dust emissions in the northern part of Sudan are still not sufficiently but slightly better represented.

\subsection{Optical thickness of Saharan dust}

In Fig. 4, the sun photometer measurements from the AERONET stations Blida, Saada, Tamanrasset, Dakar, and Agoufou (see Fig. 3a for their geographical location) show a clear seasonal cycle in the loading of coarse-mode particles, i.e., mineral dust. High AOT values are generally observed in spring and in JJAS, whereas dust emission and transport are minimum during winter. In JJAS, the monthly mean AOT reaches values of up to 0.3 at Blida in the northern Sahara (Fig. 4a), and maxima up to 0.6 occur at Agoufou in the Sahel (Fig. 4d). The seasonal variation and magnitude of dust loads are well reproduced by the model results, especially for Blida and Saada (Fig. 4a, b). Here, discrepancies mainly occur in early summer, which may be explained by a misrepresentation of moist convective dust events in the model. The absence of dust emissions in the northern Sahara from October to January (cf. Fig. 3) is an important reason for the slight underestimation during this period. More noticeable discrepancies between observations and model re-
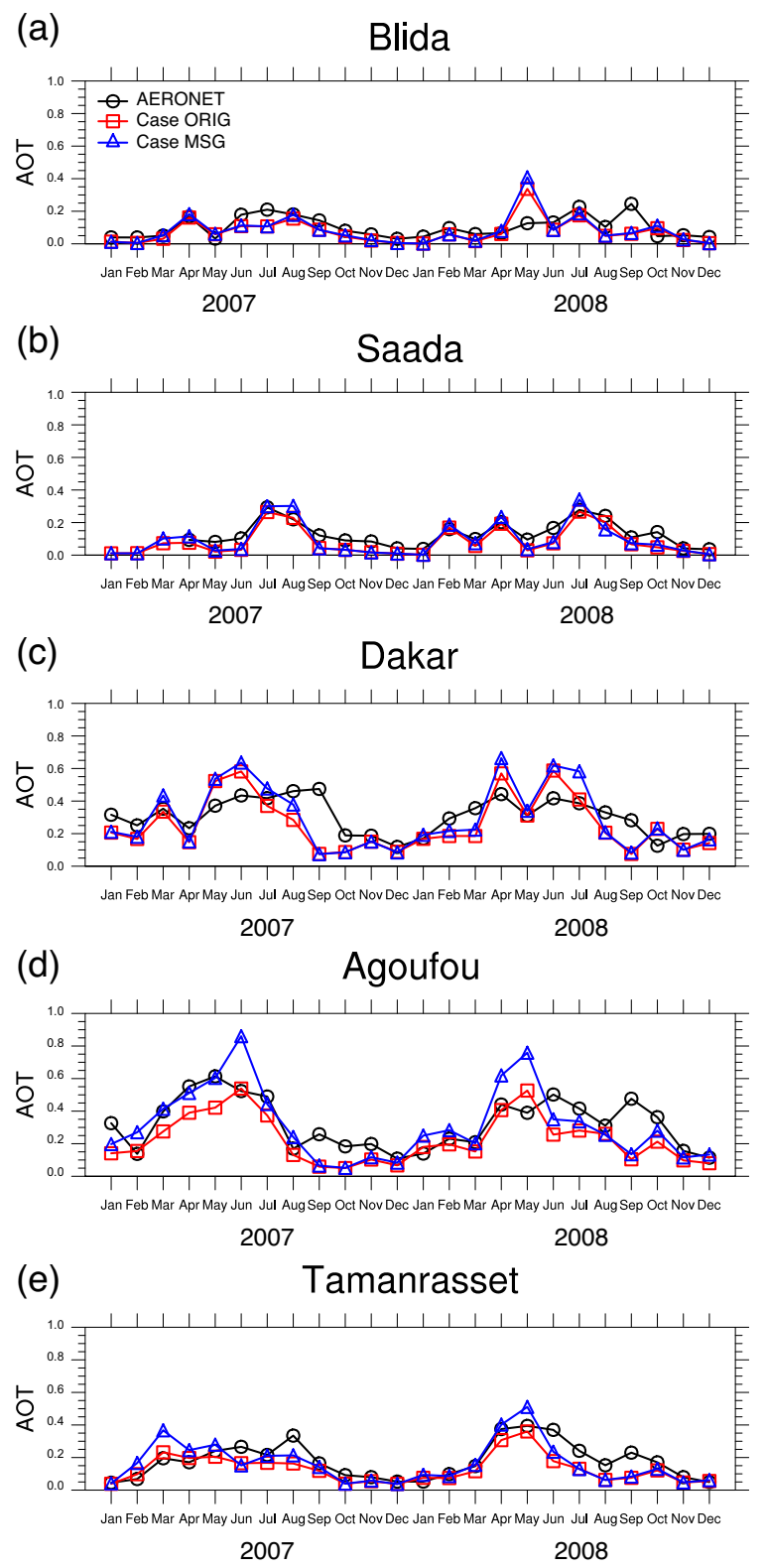

Figure 4. Time series of monthly averages of aerosol optical thickness (AOT) at Blida $\left(36.5^{\circ} \mathrm{N}, 2.9^{\circ} \mathrm{E}\right)$, Saada $\left(31.6^{\circ} \mathrm{N}, 8.2^{\circ} \mathrm{W}\right)$, Dakar $\left(14.4^{\circ} \mathrm{N}, 17.0^{\circ} \mathrm{W}\right)$, Agoufou $\left(15.3^{\circ} \mathrm{N}, 1.5^{\circ} \mathrm{W}\right)$, and Tamanrasset $\left(22.8^{\circ} \mathrm{N}, 5.5^{\circ} \mathrm{E}\right)$ for the years 2007 and 2008. Compared is the AERONET $500 \mathrm{~nm}$ coarse-mode data (black line) at quality level 1.5 (2.0 for Blida) and the modeled dust AOT from ECHAMHAM runs with the MSG-based source mask (blue line) and (red line) with the original map of preferential dust sources.

sults are evident at the Sahel stations Dakar and Agoufou (Fig. 4c, d) in spring and in particular in late summer. Although the observed coarse-mode AOT is dominated by mineral dust, other (usually fine mode) aerosols, like biomass burning smoke and anthropogenic aerosol, may also partly contribute. Biomass burning smoke contributes considerably to the aerosol load in the Sahel region mainly from Octo- 


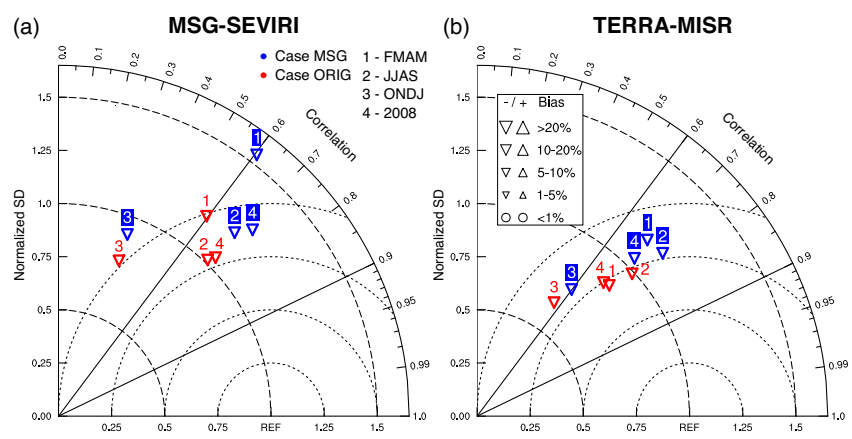

Figure 5. Taylor diagrams comparing the modeled dust optical thickness over North Africa $\left(20^{\circ} \mathrm{W}-40^{\circ} \mathrm{E}, 5^{\circ} \mathrm{N}-40^{\circ} \mathrm{N}\right)$ from ECHAM-HAM runs using the (blue) MSG source mask and (red) original setup with the dust AOT retrieval from MSG-SEVIRI (left panel) and (right panel) the TERRA-MISR AOT (daytime overpasses). Compared are seasonal averages for the months FebruaryMay, June-September, and October-January, and the annual average for the year 2008. The inset in each plot shows the scale for the mean bias.

ber to May, which may be the reason for the underestimation in these months. Sea salt and urban aerosol plays an additional important role at Dakar. A good agreement is also found for Tamanrasset in the Hoggar Mountains (Fig. 4e). This is surprising, as models usually tend to underestimate wind speeds and dust emissions in mountainous terrain. On the other hand, Saharan dust transport affects the mountain station Tamanrasset, which is located at $1377 \mathrm{~m}$ a.s.l., and the discrepancies during summertime most likely result from missed emission events related to moist convection, which large-scale models often struggle to reproduce.

The results from the two ECHAM6-HAM2 setups are very similar in particular at those locations where the dust emission is strongly controlled by mesoscale features that are not captured by the model with either setup (e.g., for JJAS in the location of Blida where cold-pool outflows from small-scale precipitation events are expected to play an important role for dust emissions). The model run with a MSG-based source mask further increases the dust optical thickness during dust events that are already captured by the original model. This leads to some improvements particularly in the central Sahara and Sahel, although the new model tends to overestimate the peaks of maxima (Fig. 4c, d, e). Here, a careful re-tuning of the wind stress correction factor (see Sect. 2) might be required.

Taylor diagrams (Taylor, 2001) are used to concisely evaluate the geographical distribution of modeled dust against the dust optical thickness from MSG-SEVIRI observations and the TERRA-MISR aerosol optical thickness for the year 2008. The Taylor diagrams in Fig. 5 show spatial statistics for a domain centered over North Africa with the lower left corner at $\left(5^{\circ} \mathrm{N}, 20^{\circ} \mathrm{W}\right)$ and the upper right corner at $\left(40^{\circ} \mathrm{N}\right.$, $\left.40^{\circ} \mathrm{E}\right)$. The satellite dust retrievals are remapped to the model grid spacing of $1.875^{\circ}$ for fair comparison with the simulations. Again, averages are calculated over months with similar meteorological conditions causing dust emissions and for the whole year 2008. The associated contour plots are presented in Fig. 6. Essentially, they show the enormous discrepancies between the model results and observations, but also the dramatic differences among the satellite retrievals, which indicate the large uncertainties in the field of spaceborne aerosol detection over land.

Particularly remarkable is the fact that the MSG dust AOT (Fig. 6a, e, i) is up to a factor of 2 higher than the MISR AOT (Fig. 6b, f, j), especially in spring and fall. This may be explained by the low temporal resolution of the MISR product, but more likely by the different sensitivities of the satellite instruments to variations in the meteorological conditions. While performing well during intense dust events, SEVIRI tends to overestimate AOT at low dust loadings and high atmospheric water content. Meanwhile MISR may be more likely to saturate at high dust loadings (Banks et al., 2013). The color-coded dots in Fig. 6, which show the seasonal mean of coarse-mode AOT at AERONET stations already used in Fig. 4, indicate that the MSG product likely overestimates the AOT of Saharan dust. However, too high values of AOT were also detected by MISR at least in summer, when mineral dust is the predominant aerosol type.

Figure 5a suggests a good agreement in the spatial dust distribution between model results and SEVIRI dust optical thicknesses, but with a clear seasonal dependence. For the standard ECHAM6-HAM2, the correlation coefficient reaches up to 0.69 in summer, but drops to 0.36 in October to January ( 0.70 for the whole year). Interestingly, Banks and Brindley (2013) also found higher biases in boreal winter when comparing their dust AOT data to AERONET measurements. Because of the overestimation of the MSG dust product (see Fig. 6), there is a large negative bias in modeled dust AOT, which on average ranges from -50 to $-80 \%$. The spatial variability is reflected by the standard deviation. Except from the months February to May, the standard setup shows slightly higher variability than the SEVIRI dust retrieval with measured standard deviations between 0.08 (OctoberJanuary) and 0.16 (June-September). This corresponds well to the strong spatial diversity with deep, local dust plumes related to moist convection over West Africa in summer in contrast to the weaker dust activities in fall or more largescale driven events from February to May.

In the Taylor diagrams improvements by the new MSGbased setup of ECHAM6-HAM2 are indicated by a decrease in the distance to the reference point marked by "REF" on the abscissa. Using the MSG dust source mask, the negative biases are partly reduced during all seasons (indicated by a colored symbol background) and the correlation is slightly improved. The spatial variability is increased by $16 \%$ (October-January) to $32 \%$ (February to May) relative to the standard setup, which is in accordance with the findings seen in Fig. 2. 

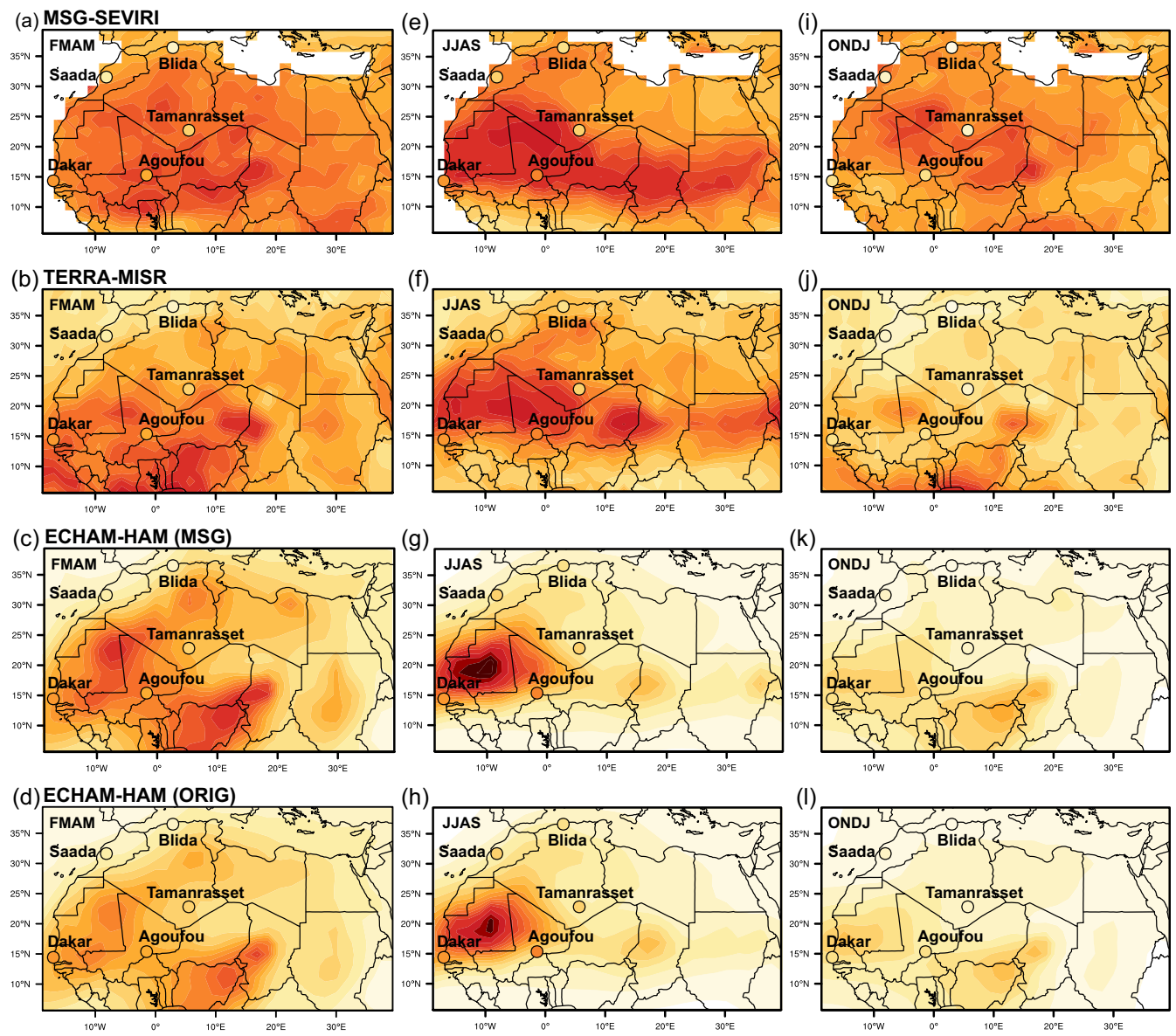

(h)
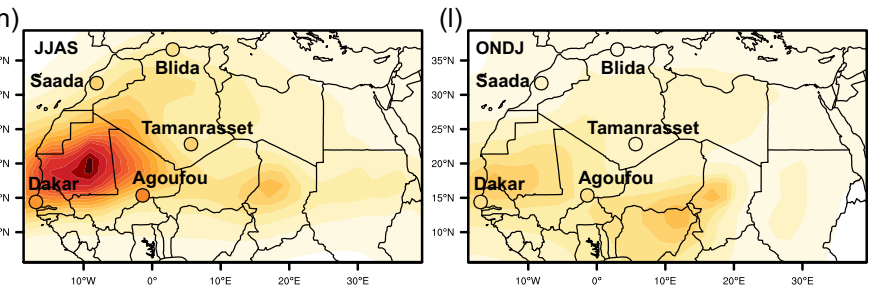

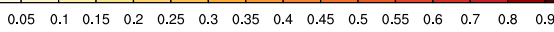
Saharan dust AOT

Figure 6. Saharan dust optical thickness for the year 2008, averaged over the months (a-d) February-May, (e-h) June-September, and (i-l) October-January. Compared are (a, e, i) values of dust AOT from MSG-SEVIRI, (b, f, $\mathbf{j})$ the TERRA-MISR AOT, and results from ECHAM-HAM model runs with the $(\mathbf{c}, \mathbf{g}, \mathbf{k})$ MSG-based and $(\mathbf{d}, \mathbf{h}, \mathbf{l})$ original setup. Color-coded dots show the corresponding average of the $500 \mathrm{~nm}$ coarse-mode AOT measured at AERONET stations.

In addition, the model results are compared to MISR aerosol optical thicknesses in Fig. 5b. The level of agreement is similar as in Fig. 5a, with the correlation coefficient ranging between 0.56 and 0.74 , but showing notably less seasonal variation in the uncertainties. The mean bias is also highly negative, but approximately $15 \%$ smaller than in the comparison with the SEVIRI dust retrieval, which corresponds well to the discrepancy between the two satellite products (Fig. 6). The spatial variability of the modeled dust distribution is about three-fourths of what is seen by MISR, except for the period June to September when it fits the observations in the standard model run. Here, the effect of using the MSG-based source mask is to lower the bias by $10-45 \%$ and to increase the standard deviation towards a better agreement with the observations in spring and fall, as well as for the whole year 2008 (Fig. 5b).

\subsection{Sub-daily dust emission frequencies}

The sub-daily information available from the MSG dust observations can be used to infer the meteorological mechanisms causing dust emissions and to evaluate their model representation. Since mesoscale models are expected to perform better than coarse-resolved climate models, we will first compare the MSG dust index observations to Saharan dust simulations with the regional model system COSMOMUSCAT. A detailed description and evaluation of the 2year model run using COSMO-MUSCAT can be found in Tegen et al. (2013). And second, we will relate the ECHAM6-HAM2 results to this comparison.

Figure 7 shows monthly totals of DSA frequencies, including time-of-day information on the dust emission onset. The observed DSA frequencies in Fig. 7a are dominated by emissions in the morning hours between 06:00 and 12:00 UTC, which points towards the breakdown of the LLJ 
(a)

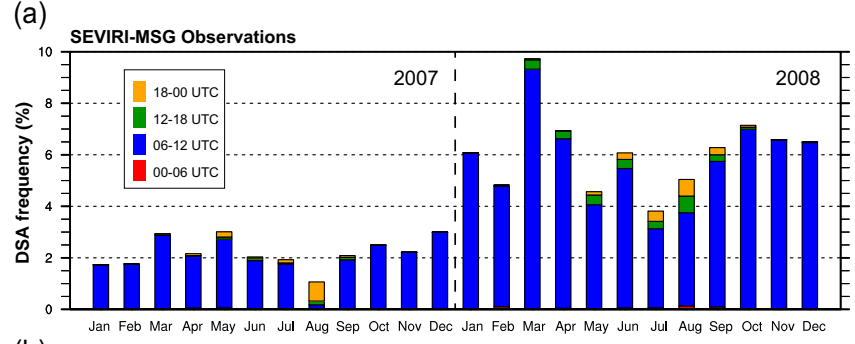

(b)

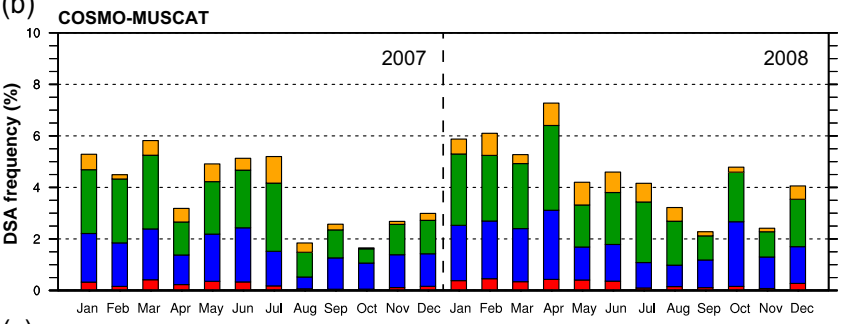

(c) ECHAM-HAM (MSG)

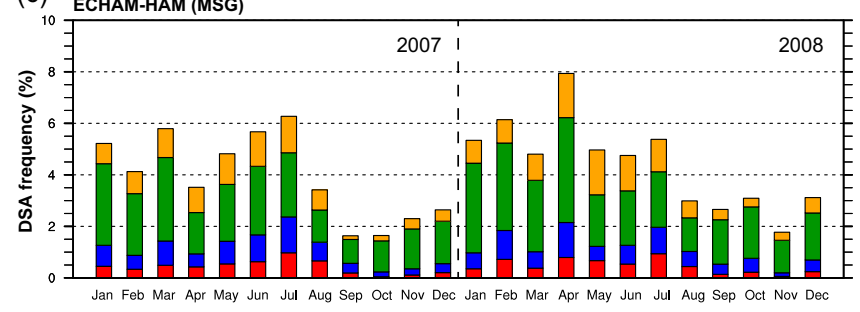

Figure 7. Monthly totals of sub-daily frequencies of Saharan dust source activations for the years 2007 and 2008. The emission events were derived from (a) the MSG infrared dust index and dust computations with (b) the regional dust model COSMO-MUSCAT and (c) the ECHAM-HAM model using the MSG-based source mask.

as the key driver of Saharan dust emissions, as already mentioned above (Schepanski et al., 2009). To a minor extent also afternoon and nighttime emission events contribute between May and September, except for August 2007, for which DSA from 18:00 to 00:00 UTC predominate. Dust emissions at this time of day are usually related to the cold outflow from moist convective systems (Schepanski et al., 2009; Knippertz and Todd, 2012). The MSG dust index observations show a strong inter-annual variability with an increase in DSA frequencies from the year 2007 to 2008 of more than $100 \%$, but a less clear variation from season to season (Fig. 7a).

Meanwhile COSMO-MUSCAT computes a pronounced seasonal cycle in the monthly frequencies of Saharan dust emission events with a maximum in spring and summer. In the model results, however, notably more DSAs occur in 2007, and the number of DSAs increase less dramatically by only $27 \%$ from 2007 to 2008 (Fig. 7b). The regional model cannot reproduce the high frequency of morning DSAs. Nonetheless, an average contribution of $40 \%$ by emission events during morning hours indicates that the breakdown of the LLJ also plays an important role in the model. The underestimation of morning DSAs may be due to a misrepresentation of the stable nocturnal stratification by the boundary layer scheme, which results in frequent downward mixing of LLJ momentum and too weak jets at nighttime, as well as a delayed and too gradual morning breakdown (Todd et al., 2008; Schepanski et al., 2009; Heinold et al., 2011; Fiedler et al., 2015). Accordingly, more dust emission events are computed between 12:00 and 18:00 UTC with approximately $45 \%$ on average, followed by a still significant contribution of DSAs between 18:00 and 00:00 UTC (Fig. 7b). As mentioned before, the dust uplift during late afternoon and evening is typically caused by convective cold pools (Knippertz and Todd, 2012). Aged cold pools and intermittent mixing of momentum from LLJs frequently produce dust-generating winds at night (Heinold et al., 2013; Fiedler et al., 2013). The cold outflow from moist convection, however, is not expected to occur in COSMO-MUSCAT, as moist convection is parameterized (Reinfried et al., 2009; Marsham et al., 2013). It is more likely that the dust emissions between noon and afternoon are modeled because of the reasons above and because of the downward mixing of momentum from a strong-wind layer in the free troposphere once the daytime boundary layer has grown sufficiently thick (Fiedler et al., 2015).

On the other hand, we should discuss the possibility that the MSG DSA observations and, thus, the model evaluation may be biased towards morning dust emissions. Afternoon to nighttime dust events mostly occur under clouds and thus cannot be detected, while dust emissions between morning and noon tend to occur under clear-sky conditions (Heinold et al., 2013). Further uncertainties in the MSG observations exist due to the sensitivity to atmospheric water vapor, the altitude of the dust layer, and the low contrast in the infrared signal between desert surface and dust at night (Ashpole and Washington, 2012; Brindley et al., 2012). At least for summer, ground-based observations in the central Sahara (Allen et al., 2013; Marsham et al., 2013) and convection-permitting simulations for West Africa (Heinold et al., 2013) show a much larger contribution (30-50\%) by convective cold pools in the late afternoon and evening. Taking this into account, the model underestimation of morning dust emission events compared to the MSG observations appears less dramatic. However, a potentially larger contribution by afternoon and evening DSAs in the model would still be due to the wrong meteorological mechanisms, as discussed above.

ECHAM6-HAM2 and COSMO-MUSCAT show very similar results regarding seasonality and inter-annual variability. Again, there is a clear seasonal cycle with a spring and summer maximum (cf. Fig. 2), but the increase in dust source activity in 2008 is less pronounced in the ECHAM6HAM2 simulations with an increase in the DSA frequencies by less than $20 \%$. In particular, the increase in DSAs in the second half of 2008 is slightly better represented by the regional model. The number of morning dust emission events is significantly reduced compared to COSMO-MUSCAT results, while most dust emission events in ECHAM6-HAM2 occur from 12:00 to 18:00 UTC. In addition, there is a 
large contribution of DSAs computed between 18:00 and 00:00 UTC as well as from 00:00 to 06:00 UTC (Fig. 7c). This indicates that the representation of stable nighttime conditions, which is a prerequisite for nocturnal LLJ formation, is even worse in the global model. Using the MSG-based source mask, we find a minor increase in the number of DSAs from 12:00 to 18:00 UTC. Moreover, there is a reduction in modeled DSAs in April 2007 by $25 \%$ and a $50 \%$ increase in August 2008, compared to the original setup (not shown), leading towards a better agreement with the MSG observations.

The comparison shows that the representation of the meteorological drivers of dust emissions is still an important issue in dust modeling on both global and regional scales. COSMO-MUSCAT by design resolves more mesoscale features and is, therefore, better but not yet satisfyingly able to represent the importance of LLJs for dust uplift. Reproducing cold-pool related dust emissions is equally problematic for the regional and global model, because of the parameterization of moist convection (Marsham et al., 2011).

\section{Summary}

The aerosol-climate model ECHAM6-HAM2 is tested with an alternative description of potential dust sources in the Sahara. A $1^{\circ} \times 1^{\circ}$ map of dust source activation frequencies compiled from MSG IR dust index observations over the period 2006 to 2010 is used to replace the original source area parameterization, which assumes the co-location of potential sources and enclosed topographic depressions. The potential of the new, observation-based setup is demonstrated in a case study, running the model in nudged mode for the years 2007 and 2008. The model results are evaluated against maps of DSA events derived from MSG IR dust index imagery, AERONET sun photometer measurements, and satellite AOT retrievals. In addition, sub-daily DSA frequency information from MSG was used to evaluate the model representation of meteorological drivers of Saharan dust emission.

Using the MSG-based source map yields a more realistic geographical distribution of Saharan dust emission events. The dust production is increased by about $20 \%$ compared to the original model. The higher annual total of Saharan dust emissions agrees well with the estimate from other recent global aerosol-climate models, taking into account the small cut-off size for dust particles in ECHAM6-HAM2. The month-by-month analysis shows that dust production is mainly increased as result of a larger temporal variability while the monthly median is less affected, except for summer months, when more sources in the southern Sahara and Sahel are activated.

Generally, there is a good agreement between modeled dust optical thickness and AERONET coarse-mode AOT, and only minor differences occur between the two model versions for the northern Sahara. The new setup mainly causes an increase in the dust load during events that are also captured by the standard ECHAM6-HAM2. An improvement in the modeled dust optical thickness is found in the southern Sahara and Sahel region despite an overestimation of summertime maxima. The latter can be avoided by slightly retuning the dust scheme in future studies.

When compared to satellite retrievals of dust and aerosol optical thickness from MSG-SEVIRI and MISR, respectively, reasonably high correlations between the model results and observations indicate a good representation of the spatial dust distribution. A likely overestimation of AOT by the satellite retrievals complicates the comparison and lets the model results in general appear too low. With the MSG-based source map, the bias is partly reduced in October to January, a period showing large uncertainties, and in spring. The spatial variability is increased towards a somewhat higher level of agreement depended on the season.

The evaluation with sub-daily dust information from MSG-SEVIRI shows that the representation of the meteorological drivers of Saharan dust emissions remains a critical issue for ECHAM6-HAM2 as it is for other global models. In comparison to the MSG observations and results from the regional dust model COSMO-MUSCAT, the model dramatically underestimates the important fraction of dust emissions related to the morning breakdown of the nocturnal low level jet due to poorly reproduced stable nighttime conditions. Instead a major contribution comes from afternoon-to-evening emission events, caused by delayed LLJ breakdowns, downward mixing of momentum from free-tropospheric layers during the day, and artificially high mixing at nighttime. Particularly problematic is also the representation of moist convective dust uplift in either regional or global models because of the parameterization of moist convection.

We assume that constraining Saharan dust sources by satellite observations can partly compensate for uncertainties in soil properties and the misrepresentation of dustgenerating winds. However, the improvements seen in this study are less important than expected from the simulations with the regional dust model COSMO-MUSCAT, in which the MSG source map was successfully tested before. Possibly, the benefit of prescribing potential dust sources by satellite-derived DSA frequencies has a more important effect on free-running models, whose wind fields show larger uncertainties (Timmreck and Schulz, 2004). Thus, additional free climate runs, together with a systematic investigation of dust-generating winds, are needed for a concluding evaluation of the potential of the MSG-based source map in ECHAM6-HAM2.

The current update is not exhaustive, and in particular the surface roughness, which is an important parameter in the dust emission process, requires a more sophisticated consideration. The challenge of future model developments, therefore, may be to describe the surface roughness at process scale, for example, by computing subgrid-scale dust emis- 
sion fluxes at the resolution level of high-resolved roughness length data from satellite remote sensing.

\section{Code availability}

The ECHAM6-HAMMOZ model is made available to the scientific community under the HAMMOZ Software Licence Agreement. Further details on accessing the source code are given on the HAMMOZ website: https://redmine.hammoz.ethz.ch/projects/hammoz/ wiki/Distribution. ECHAM6-HAMMOZ is provided together with all necessary input data, including the new MSGbased dust source activation (DSA) map, at grid resolutions between $\mathrm{T} 31$ and $\mathrm{T} 255$.

Acknowledgements. We thank P. Goloub, B. Holben, D. Tanré, B. Mougenot, and E. Cuevas-Agullo for their efforts in establishing and maintaining the AERONET sites Agoufou, Blida, Dakar, Saada, and Tamanrasset. The MISR data were obtained from the NASA Langley Research Center Atmospheric Science Data Center. The ECHAM-HAMMOZ model is developed by a consortium, which is composed of the ETH Zurich, Max Planck Institute for Meteorology, Jülich Research Center, University of Oxford, and Finnish Meteorological Institute, and managed by the Center for Climate Systems Modeling (C2SM) at ETH Zurich. The simulations were performed at the German Climate Computing Center (DKRZ), Hamburg/Germany and the John von Neumann Institute for Computing (NIC), Jülich/Germany.

Edited by: A. Kerkweg

\section{References}

Allen, C. J. T., Washington, R., and Engelstaedter, S.: Dust emission and transport mechanisms in the central Sahara: Fennec ground-based observations from Bordj Badji Mokhtar, June 2011, J. Geophys. Res. Atmos., 118, 6212-6232, doi:10.1002/jgrd.50534, 2013.

Ashpole, I. and Washington, R.: An automated dust detection using SEVIRI: A multi-year climatology of summertime dustiness in the central and western Sahara, J. Geophys. Res., 117, D08202, doi:10.1029/2011JD016845, 2012.

Baker, J. B., Southard, R. J. and Mitchell, J. P.: Agricultural Dust Production in Standard and Conservation Tillage Systems in the San Joaquin Valley, J. Environ. Qual., 34, 1260-1269, doi:10.2134/jeq2003.0348, 2005.

Banks, J. R. and Brindley, H. E.: Evaluation of MSGSEVIRI mineral dust retrieval products over North Africa and the Middle East, Remote Sens. Environ., 128, 58-73, doi:10.1016/j.rse.2012.07.017, 2013.

Banks, J. R., Brindley, H. E., Flamant, C., Garay, M. J., Hsu, N. C., Kalashnikova, O. V., Klüser, L., and Sayer, A. M.: Intercomparison of satellite dust retrieval products over the west African Sahara during the Fennec campaign in June 2011, Remote Sens. Environ., 136, 99-116, doi:10.1016/j.rse.2013.05.003, 2013.

Ben-Ami, Y., Koren, I., Altaratz, O., Kostinski, A., and Lehahn, Y.: Discernible rhythm in the spatio/temporal distributions of transatlantic dust, Atmos. Chem. Phys., 12, 2253-2262, doi:10.5194/acp-12-2253-2012, 2012.

Boucher, O., Randall, D., Artaxo, P., Bretherton, C., Feingold, G., Forster, P., Kerminen, V. M., Kondo, Y., Liao, H., Lohmann, U., Rasch, P., Satheesh, S., Sherwood, S., Stevens, B., and Zhang, X.: Clouds and Aerosols, in: Climate Change 2013: The Physical Science Basis, Contribution of Working Group I to the Fifth Assessment Report of the Intergovernmental Panel on Climate Change, Cambridge University Press, Cambridge, United Kingdom and New York, NY, USA, 2013.

Breitkreuz, H., Schroedter-Homscheidt, M., and Holzer-Popp, T.: A case study to prepare for the utilization of aerosol forecasts in solar energy industries, Sol. Energy, 81, 1377-1385, doi:10.1016/j.solener.2007.01.009, 2007.

Brindley, H. E. and Russell, J. E.: An assessment of Saharan dust loading and the corresponding cloud-free longwave direct radiative effect from geostationary satellite observations, J. Geophys. Res., 114, D23201, doi:10.1029/2008JD011635, 2009.

Brindley, H., Knippertz, P., Ryder, C., and Ashpole, I.: A critical evaluation of the ability of the Spinning Enhanced Visible and Infrared Imager (SEVIRI) thermal infrared red-green-blue rendering to identify dust events: Theoretical analysis, J. Geophys. Res.-Atmos., 117, D07201, doi:10.1029/2011JD017326, 2012.

Carslaw, K. S., Boucher, O., Spracklen, D. V., Mann, G. W., Rae, J. G. L., Woodward, S., and Kulmala, M.: A review of natural aerosol interactions and feedbacks within the Earth system, Atmos. Chem. Phys., 10, 1701-1737, doi:10.5194/acp-10-17012010, 2010.

Cheng, T., Peng, Y., Feichter, J., and Tegen, I.: An improvement on the dust emission scheme in the global aerosol-climate model ECHAM5-HAM, Atmos. Chem. Phys., 8, 1105-1117, doi:10.5194/acp-8-1105-2008, 2008.

Fiedler, S., Schepanski, K., Heinold, B., Knippertz, P., and Tegen, I.: Climatology of nocturnal low-level jets over North Africa and implications for modeling mineral dust emission, J. Geophys. Res.-Atmos., 118, 6100-6121, doi.10.1002/jgrd.50394, 2013.

Fiedler, S., Schepanski, K., Knippertz, P., Heinold, B., and Tegen, I.: How important are atmospheric depressions and mobile cyclones for emitting mineral dust aerosol in North Africa?, Atmos. Chem. Phys., 14, 8983-9000, doi:10.5194/acp-14-8983-2014, 2014.

Fiedler, S., Knippertz, P., Woodward, S., Martin, G. M., Bellouin, N., Ross, A. N., Heinold, B., Schepanski, K., Birch, C. E., and Tegen, I.: A process-based evaluation of winds important for dust emission in the CMIP5 simulation of HadGEM2-ES, Clim. Dynam., 46, 1107-1130, doi:10.1007/s00382-015-2635-9, 2015.

Ginoux, P., Prospero, J. M., Gill, T. E., Hsu, N. C., and Zhao, M.: Global-scale attribution of anthropogenic and natural dust sources and their emission rates based on MODIS Deep Blue aerosol products, Rev. Geophys., 50, RG3005, doi:10.1029/2012RG000388, 2012.

Griffin, D. W.: Atmospheric movement of microorganisms in clouds of desert dust and implications for human health, Clin. Microbiol. Rev., 20, 459-477, doi:10.1128/CMR.00039-06, 2007.

Hannachi, A., Awad, A., and Ammar, K.: Climatology and classification of Spring Saharan cyclone tracks, Clim. Dynam., 37, 473-491, doi.10.1007/s00382-010-0941-9, 2011.

Heinold, B., Helmert, J., Hellmuth, O. , Wolke, R., Ansmann, A., Marticorena, B., Laurent, B., and Tegen, I.: Regional modeling of Saharan dust events using LM-MUSCAT: Model descrip- 
tion and case studies, J. Geophys. Res.-Atmos., 112, D11204, doi:10.1029/2006JD007443, 2007.

Heinold, B., Tegen, I., Schepanski, K., Tesche, M., Esselborn, M., Freudenthaler, V., Gross, S., Kandler, K., Knippertz, P., Müller, D., Schladitz, A., Toledano, C., Weinzierl, B., Ansmann, A., Althausen, D., Müller, T., Petzold, A., and Wiedensohler, A.: Regional modelling of Saharan dust and biomass-burning smoke Part I: Model description and evaluation, Tellus B, 63, 781-799, doi:10.1111/j.1600-0889.2011.00570.x, 2011.

Heinold, B., Knippertz, P., Marsham, J. H., Fiedler, S., Dixon, N. S., Schepanski, K., Laurent, B., and Tegen, I.: The role of deep convection and nocturnal low-level jets for dust emission in summertimeWest Africa: Estimates from convectionpermitting simulations, J. Geophys. Res.-Atmos., 118, 1-16, doi:10.1002/jgrd.50402, 2013.

Holben, B. N., Eck, T. F., Slutsker, I., Tanré, D., Buis, J. P., Setzer, A., Vermote, E., Reagan, J. A., Kaufinan, Y. J., Nakajima, T., Lavenu, F., Jankowiak, I., and Smirnov, A.: AERONET A federated instrument network and data archive for aerosol characterization, Remote Sens. Environ., 66, 1-16, doi:10.1016/S00344257(98)00031-5, 1998.

Huneeus, N., Schulz, M., Balkanski, Y., Griesfeller, J., Prospero, J., Kinne, S., Bauer, S., Boucher, O., Chin, M., Dentener, F., Diehl, T., Easter, R., Fillmore, D., Ghan, S., Ginoux, P., Grini, A., Horowitz, L., Koch, D., Krol, M. C., Landing, W., Liu, X., Mahowald, N., Miller, R., Morcrette, J.-J., Myhre, G., Penner, J., Perlwitz, J., Stier, P., Takemura, T., and Zender, C. S.: Global dust model intercomparison in AeroCom phase I, Atmos. Chem. Phys., 11, 7781-7816, doi:10.5194/acp-11-7781-2011, 2011.

Jemmett-Smith, B. C., Marsham, J. H., Knippertz, P., and Gilkeson, C. A.: Quantifying global dust devil occurrence from meteorological analyses, Geophys. Res. Lett., 42, 1275-1282, doi:10.1002/2015GL063078, 2015.

Kahn, R., Li, W., Moroney, C., Diner, D., Martonchik, J., and Fishbein, E.: Aerosol source plume physical characteristics from space-based multiangle imaging, J. Geophys. Res, 112, D11205, doi:10.1029/2006JD007647, 2007.

Kahn, R. A., Nelson, D. L., Garay, M. J., Levy, R. C., Bull, M. A., Diner, D. J., Martonchik, J. V., Paradise, S. R., Hansen, E. G., and Remer, L. A.: MISR aerosol product attributes and statistical comparisons with MODIS, IEEE Trans. Geosci. Remote Sens., 47, 4095-4114, doi:10.1109/tgrs.2009.2023115, 2009.

Kahn, R. A., Gaitley, B. J., Garay, M. J., Diner, D. J., Eck, T. F., Smirnov, A., and Holben, B. N.: Multiangle Imaging SpectroRadiometer global aerosol product assessment by comparison with the Aerosol Robotic Network, J. Geophys. Res., 115, D23209, doi:10.1029/2010JD014601, 2010.

Kalu, A. E.: The African dust plume: Its characteristics and propagation across West Africa in winter, in: Saharan Dust, edited by: Morales, C., John Wiley Sons, Chichester, 95-118, 1979.

Knippertz, P.: Dust mobilization in the West African heat trough - the role of the diurnal cycle and of extratropical synoptic disturbances, Meteorol. Z., 17, 553-563, doi:10.1127/09412948/2008/0315, 2008.

Knippertz, P. and Todd, M. C.: Mineral dust aerosols over the Sahara: Meteorological con-trols on emission and transport and implications for modeling, Rev. Geophys., 50, RG1007, doi:10.1029/2011RG000362, 2012.
Knippertz, P., Trentmann, J., and Seifert, A.: High-resolution simulations of convective cold pools over the northwestern Sahara, J. Geophys. Res.-Atmos., 114, D08110, doi:10.1029/2008JD011271, 2009.

Knippertz, P., Tesche, M. Heinold, B., Kandler, K., Toledano, C., and Esselborn, M.: Dust mobilization and aerosol transport from West Africa to Cape Verde - A meteorological overview of SAMUM-2, Tellus B, 63, 430-447, doi:10.1111/j.16000889.2011.00544.x, 2011.

Koch, J. and Renno, N. O.: The role of convective plumes and vortices on the global aerosol budget, Geophys. Res. Lett., 32, L18806, doi:10.1029/2005GL023420, 2005.

Lohmann, U., Stier, P., Hoose, C., Ferrachat, S., Kloster, S., Roeckner, E., and Zhang, J.: Cloud microphysics and aerosol indirect effects in the global climate model ECHAM5-HAM, Atmos. Chem. Phys., 7, 3425-3446, doi:10.5194/acp-7-3425-2007, 2007.

Luo, C., N. Mahowald, M. and del Corral, J.: Sensitivity study of meteorological parameters on mineral aerosol mobilization, transport, and distribution, J. Geophys. Res., 108, 4447, doi:10.1029/2003JD003483, 2003.

Marticorena, B. and Bergametti, G.: Modeling the atmospheric dust cycle: 1. Design of a soil-derived dust emission scheme, J. Geophys. Res., 100, 16415-16430, doi:10.1029/95JD00690, 1995.

Marsham, J. H., Knippertz, P., Dixon, N. S., Parker, D. J., and Lister, G. M. S.: The importance of the representation of deep convection for modeled dust-generating winds overWest Africa during summer, Geophys. Res. Lett., 38, L16803, doi:10.1029/2011GL048368, 2011.

Marsham, J. H., Hobby, M., Allen, C. J. T., Banks, J. R., Bart, M., Brooks, B. J., Cavazos-Guerra, C., Engelstaedter, S., Gascoyne, M., Lima, A. R., Martins, J. V., McQuaid, J. B., O’Leary, A., Ouchene, B., Ouladichir, A., Parker, D. J., Saci, A., SalahFerroudj, M., Todd, M. C., and Washington, R.: Meteorology and dust in the central Sahara: Observations from Fen-nec supersite1 during the June 2011 Intensive Observation Period, J. Geophys. Res. Atmos., 118, 4069-4089, doi:10.1002/jgrd.50211, 2013.

Menut, L.: Sensitivity of hourly Saharan dust emissions to NCEP and ECMWF modeled wind speed, J. Geophys. Res., 113, D16201, doi:10.1029/2007JD009522, 2008.

Mulcahy, J. P., Walters, D. N., Bellouin, N., and Milton, S. F.: Impacts of increasing the aerosol complexity in the Met Office global numerical weather prediction model, Atmos. Chem. Phys., 14, 4749-4778, doi:10.5194/acp-14-4749-2014, 2014.

O’Neill, N. T., Eck, T. F., Smirnov, A., Holben, B. N., and Thulasiraman, S.: Spectral discrimination of coarse and fine mode optical depth, J. Geophys. Res., 108, 4559, doi:10.1029/2002JD002975, 2003.

Prigent, C., Tegen, I., Aires, F., Marticorena, B., and Zribi, M.: Estimation of the aerodynamic roughness length in arid and semiarid regions over the globe with the ERS scatterometer, J. Geophys. Res., 110, D09205, doi:10.1029/2004JD005370, 2005.

Prospero, J. M., Ginoux, P., Torres, O., Nicholson, S., and Gill, T.: Environmental characterization of global sources of atmospheric soil dust identified with the NIMBUS7 Total Ozone Mapping Spectrometer (TOMS) absorbing aerosol product, Rev. Geophys., 40, 1002, doi:10.1029/2000RG000095, 2002.

Reinfried, F., Tegen, I., Heinold, B., Hellmuth, O., Schepanski, K., Cubasch, U., Huebener, H., and Knippertz, P.: Simulations of 
convectively-driven density currents in the Atlas region using a regional model: Impacts on dust emission and sensitivity to horizontal resolution and convection schemes, J. Geophys. Res.Atmos., 114, D08127, doi:10.1029/2008JD010844, 2009.

Ridley, D. A., Heald, C. L., Pierce, J. R., and Evans, M. J.: Toward resolution-independent dust emissions in global models: Impacts on the seasonal and spatial distribution of dust, Geophys. Res. Lett., 40, 2873-2877, doi:10.1002/grl.50409, 2013.

Schepanski, K., Tegen, I., Laurent, B., Heinold, B., and Macke, A.: A new Saharan dust source activation frequency map derived from MSG-SEVIRI IR-channels, Geophys. Res. Lett., 34, L18803, doi:10.1029/2007GL030168, 2007.

Schepanski, K., Tegen, I., Todd, M. C., Heinold, B., Bönisch, G., Laurent, B., and Macke, A.: Meteorological processes forcing Saharan dust emission inferred from MSG-SEVIRI observations of subdaily dust source activation and numerical models, J. Geophys. Res., 114, D10201, doi:10.1029/2008JD010325, 2009.

Schepanski, K., Tegen, I., and Macke, A. Comparison of satellite based observations of Saharan dust source areas, Rem. Sens. Environm., 123, 90-97, doi:10.1016/j.rse.2012.03.019, 2012.

Schulz, M., Chin, M., and Kinne S.: The Aerosol Model Comparison Project, AeroCom, Phase II: Clearing up diversity, IGAC Newsletter, 41, 1-24, 2009.

Shao Y., Wyrwoll, K.-H., Chappell A., Huang, J., Lin, Z., McTainsh, G. H., Mikami, M., Tanaka, T. Y., Wang, X., and Yoon, S.: Dust cycle: An emerging core theme in Earth system science, Aeolian Res., 2, 181-204, doi:10.1016/j.aeolia.2011.02.001, 2011.

Stevens, B., Giorgetta, M., Esch, M., Mauritsen, T., Crueger, T., Rast, S., Salzmann, M., Schmidt, H., Bader, J., Block, K., Brokopf, R., Fast, I., Kinne, S., Kornblueh, L., Lohmann, U., Pincus, R., Reichler, T., and Roeckner E.: Atmospheric component of the MPI-M Earth System Model: ECHAM6, J. Adv. Model. Earth Syst., 5, 146-172, doi:10.1002/jame.20015, 2013.

Stier, P., Feichter, J., Kinne, S., Kloster, S., Vignati, E., Wilson, J., Ganzeveld, L., Tegen, I., Werner, M., Balkanski, Y., Schulz, M., Boucher, O., Minikin, A., and Petzold, A.: The aerosol-climate model ECHAM5-HAM, Atmos. Chem. Phys., 5, 1125-1156, doi:10.5194/acp-5-1125-2005, 2005.
Taylor, K.: Summarizing multiple aspects of model performance in a single diagram, J. Geophys. Res., 106, 7183-7192, doi:10.1029/2000JD900719, 2001.

Tegen, I., Harrison, S. P., Kohfeld, K., and Prentice, I. C.: Impact of vegetation and preferential source areas on global dust aerosol: Results from a model study, J. Geophys. Res., 107, 4576, doi:10.1029/2001JD000963, 2002.

Tegen, I., Schepanski, K., and Heinold, B.: Comparing two years of Saharan dust source activation obtained by regional modelling and satellite observations, Atmos. Chem. Phys., 13, 2381-2390, doi:10.5194/acp-13-2381-2013, 2013.

Textor, C., Schulz, M., Guibert, S., Kinne, S., Balkanski, Y., Bauer, S., Berntsen, T., Berglen, T., Boucher, O., Chin, M., Dentener, F., Diehl, T., Easter, R., Feichter, H., Fillmore, D., Ghan, S., Ginoux, P., Gong, S., Grini, A., Hendricks, J., Horowitz, L., Huang, P., Isaksen, I., Iversen, I., Kloster, S., Koch, D., Kirkevåg, A., Kristjansson, J. E., Krol, M., Lauer, A., Lamarque, J. F., Liu, X., Montanaro, V., Myhre, G., Penner, J., Pitari, G., Reddy, S., Seland, $\varnothing .$, Stier, P., Takemura, T., and Tie, X.: Analysis and quantification of the diversities of aerosol life cycles within AeroCom, Atmos. Chem. Phys., 6, 1777-1813, doi:10.5194/acp-6-1777-2006, 2006.

Timmreck, C. and Schulz, M.: Significant dust simulation differences in nudged and climatological operation mode of the AGCM ECHAM, J. Geophys. Res., 109, D13202, doi:10.1029/2003JD004381, 2004.

Todd, M. C., Washington, R., Raghavan, S., Lizcano, G., and Knippertz, P.: Regional model simulations of the Bodélé low-level jet of northern Chad during the Bodélé Dust Experiment (BoDEx 2005), J. Climate, 21, 995-1012, doi:10.1175/2007JCLI1766.1, 2008.

Zhang, K., O’Donnell, D., Kazil, J., Stier, P., Kinne, S., Lohmann, U., Ferrachat, S., Croft, B., Quaas, J., Wan, H., Rast, S., and Feichter, J.: The global aerosol-climate model ECHAM-HAM, version 2: sensitivity to improvements in process representations, Atmos. Chem. Phys., 12, 8911-8949, doi:10.5194/acp-12-89112012, 2012. 